\title{
Arthropods Vector Grapevine Trunk Disease Pathogens
}

\author{
P. Moyo, E. Allsopp, F. Roets, L. Mostert, and F. Halleen
}

First, fourth, and fifth authors: Department of Plant Pathology, University of Stellenbosch, P/Bag X1, Matieland, 7602, South Africa; second and fifth authors: Plant Protection Division, ARC Infruitec-Nietvoorbij, P/Bag X5026, Stellenbosch 7599, South Africa; and third author: Department of Conservation Ecology and Entomology, University of Stellenbosch, P/Bag X1, Matieland, 7602, South Africa. Accepted for publication 6 March 2014.

\begin{abstract}
Moyo, P., Allsopp, E., Roets, F., Mostert, L., and Halleen, F. 2014. Arthropods vector grapevine trunk disease pathogens. Phytopathology 104:1063-1069.

Arthropod-mediated dispersal of pathogens is known in many cropping systems but has never been demonstrated for grapevine trunk disease pathogens. Arthropods from vineyards were screened for the presence of pathogens associated with Petri disease and esca using cultural and molecular techniques. The ability of the most abundant pathogen-carrying species to inoculate healthy grapevine vascular tissues was also determined. Millipedes and ants were allowed to associate with a DsRedExpress-transformed Phaeomoniella chlamydospora, after which they were exposed to freshly pruned healthy grapevines under controlled conditions and wounds were monitored for subsequent infection. In

addition, the possibility of millipede excreta, commonly found on pruning wounds in the field, to act as inoculum source was determined. A diverse arthropod fauna was associated with declining grapevines and many of these carried trunk disease pathogens. However, spiders, the ant Crematogaster peringueyi, and the millipede Ommattoiulus moreleti were the most abundant pathogen carriers. The ant and millipede species fed on pruning wound sap and effectively transmitted trunk disease pathogens. Millipede excreta contained viable spores of Phaeomoniella chlamydospora and may serve as an inoculum source. Numerous arthropods, including beneficial predators, are potential vectors of grapevine trunk disease pathogens. Our results highlight the need for an integrated approach, including targeted management of ants and millipedes at the time of pruning, to limit the spread of grapevine trunk diseases.
\end{abstract}

Petri disease and esca are two grapevine trunk diseases that occur globally and result in reduced grape yield and quality and ultimately significant financial losses. Symptoms of Petri disease include stunted growth, reduced vine vigor, and wood discoloration, often observed in cross section (14), while those of esca-diseased plants include "tiger-stripe" patterns on chlorotic leaves and white rot in a cross section which is surrounded by a black or brown margin (29). Petri disease usually results from infections by Phaeomoniella chlamydospora and various Phaeoacremonium spp., and esca is caused by Petri disease fungi and basidiomycetes $(29,42)$. Fungi from the families Botryosphaeriaceae, Diaporthales, and Diatrypacaeae have recently also been isolated from esca-diseased vines (41). Numerous studies have investigated the epidemiology of Petri disease and esca; however, the dissemination of the disease-causing organisms remains uncertain. Infection sites for the pathogens are primarily fresh grapevine pruning wounds (39) and infection has previously been attributed to aerial inoculum $(15,21)$. However, recent studies failed to detect spores of these fungi from aerial sources in vineyards with high disease frequencies $(26,37)$. This suggests that these pathogens may be transmitted via other means.

$P$. chlamydospora produces pycnidia on old pruning wounds or in the cracks and crevices of infected grapevine wood (11). Perithecia of Togninia spp. the teleomorph of Phaeoacremonium, are found in cracks and crevices, or within insect tunnels, on trunks and cordons of diseased vines $(3,33)$. Perithecia produce sticky spore droplets (33), a characteristic usually associated with fungi that rely on arthropods for dispersal (22). The cracks and crevices provide a protected, humid environment favorable for both fungal sporulation (10) and arthropod colonization. This

Corresponding author: F. Halleen; E-mail address: halleenf@arc.agric.za

http://dx.doi.org/10.1094/PHYTO-11-13-0303-R

(c) 2014 The American Phytopathological Society close association between arthropods and sporulating fungi indicates a possible role for arthropods in disease epidemiology.

Evidence for possible entomochoric dispersal of trunk disease pathogens includes the association of Phaeoacremonium rubrigenum with bark beetles (20) and the presence of Diplodia seriata on rove beetles collected from grapevine pruning wounds (13). In addition, an association of collembolans and mites with sporulating structures of Phaeomoniella chlamydospora on grapevines was previously reported from Australia (10). However, no previous study has demonstrated the ability of pathogen-carrying arthropods to inoculate pruning wounds on healthy grapevines and cause infection, conditions fundamental for establishing their role in the spread of diseases (22).

Fungal spores may be transported on the exoskeleton of arthropods or through their digestive tracts. External transport of fungal spores has been established for many plant pathogens $(12,18)$. Internal transport of fungal spores by animals necessitates the excretion of viable propagules in fecal material and has been shown to contribute significantly to fungal dispersal in some systems (22) and may even enhance their germination $(5,34)$. Fecal matter also provides an immediate supply of moisture and nutrients for developing fungal hyphae and can be seen as a concentrated "spore pocket" when compared with dispersal by agents such as wind (5).

To date, there has been no direct experimental evidence to implicate arthropods as vectors of grapevine trunk disease pathogens. Therefore, the main aim of the present study was to determine whether arthropods vector pathogens associated with Petri disease and esca. We followed a stepwise approach to fulfill Leach's postulates (22) for proving arthropod transmission by determining (i) which arthropods are associated with diseased grapevines, (ii) whether these arthropods carry spores of pathogens associated with Petri disease and esca, (iii) whether the most abundant arthropods that regularly carry reproductive propagules of the pathogens visit pruning wounds, (iv) whether the main 
potential vectors of fungal reproductive propagules visit pruning wounds to feed on grapevine sap exuded after pruning, and (v) whether the identified arthropods can transfer at least one of the disease causal organisms to pruning wounds on healthy vines and cause infection. Therefore, the specific objectives of the study were (i) screening arthropod fauna for pathogen presence using both isolation and molecular techniques, (ii) evaluating their preference to feed on grapevine sap, and (iii) evaluating transmission success through contact and fecal pellets.

\section{MATERIALS AND METHODS}

Arthropod collection. Arthropods were collected from two wine grape vineyards that showed grapevine trunk disease symptoms in the Western Cape Province of South Africa. One vineyard was in the Stellenbosch region ('Pinotage', Nietvoorbij, GPS $33^{\circ} 54^{\prime} 22.3^{\prime \prime} \mathrm{S} 18^{\circ} 52^{\prime} 7.5^{\prime \prime} \mathrm{E}$ ) and the other in the Breede River Valley region ('Chenin blanc', Rawsonville, GPS $\left.33^{\circ} 39^{\prime} 34.1^{\prime \prime} \mathrm{S} 19^{\circ} 17^{\prime} 41.5^{\prime \prime} \mathrm{E}\right)$. Both vineyards are farmed conventionally, as are most vineyards in these regions. Three techniques were used to maximize numbers of arthropods collected from both diseased vines and from fresh pruning wounds on healthy vines, as described below.

Trunk and cordon traps. Traps, made from strips of cardboard (100 mm wide, with no adhesive material), were placed on 30 symptomatic vines per vineyard. Three traps were placed on each vine and held in place with binding wire: one around the trunk (between the graft union and the cordons) and one on each of the cordons. Traps were inspected weekly from May 2010 to November 2011 and all arthropods sheltering underneath the traps were collected. Collected arthropods were grouped into morphospecies and stored in sterile 14-ml McCartney bottles (Anchor Rand, Johannesburg, South Africa) either as separate individuals or in groups of up to 20 individuals of the same arthropod morphospecies until further processing. The majority of arthropods were identified at the Department of Conservation Ecology and Entomology, University of Stellenbosch, South Africa. Spiders were identified at the Arachnology unit of the Agricul- tural Research Council-Plant Protection Research Institute, South Africa. Only individuals collected from the same plant were stored in the same bottle, with the number of individuals placed together dependent on the size of individuals.

Pruning wound traps. Thirty apparently healthy vines in close proximity to the vines with trunk and cordon traps were selected in both vineyards. One shoot from each vine was pruned in midJune, another (on the same plant) 4 weeks later (July), and a third shoot was pruned in August. Pruning wound traps were designed to collect arthropods attracted to these fresh wounds. Traps were constructed from transparency film that was cut in a circular shape (150 $\mathrm{mm}$ in diameter) and folded into a funnel that was kept in position using metal staples. The bottom of the funnel was cut slightly larger than the width of the pruned shoot to which the trap was fastened, secured to the shoot using a drawing pin, and painted with Plantex (Chempac, Paarl, South Africa) to trap arthropods that were attracted to wounds. The traps were placed over the pruning wound such that more than half the length of the shoot was covered and two-thirds of the cup extended above the top of the pruned cane (Fig. 1A). Traps were replaced weekly for 4 weeks after each pruning time. Entrapped arthropods were removed and processed as previously described.

Visual surveys. Daylight visual surveys for arthropods were conducted once a week in the same vineyards and over the same period as described above. Surveys, conducted on a random number of diseased vines on each occasion, involved actively searching for arthropods on the plant surface, under loose bark, and in the cracks and crevices on the trunks and arms and at the base of diseased vines. Collected arthropods were processed similarly as those collected from the trunk and cordon traps. In addition to the daylight surveys, three nocturnal surveys were conducted in the Pinotage vineyard, a few hours after pruning of vines, to assess possible nocturnal arthropod activity on wounds.

Screening of arthropods for presence of pathogens using culturing techniques. All collected arthropods were removed from the glass bottles and placed into 2-ml Eppendorf tubes containing sterile water. Arthropods (from one bottle) were placed into more than one Eppendorf tube if there were too many to fit
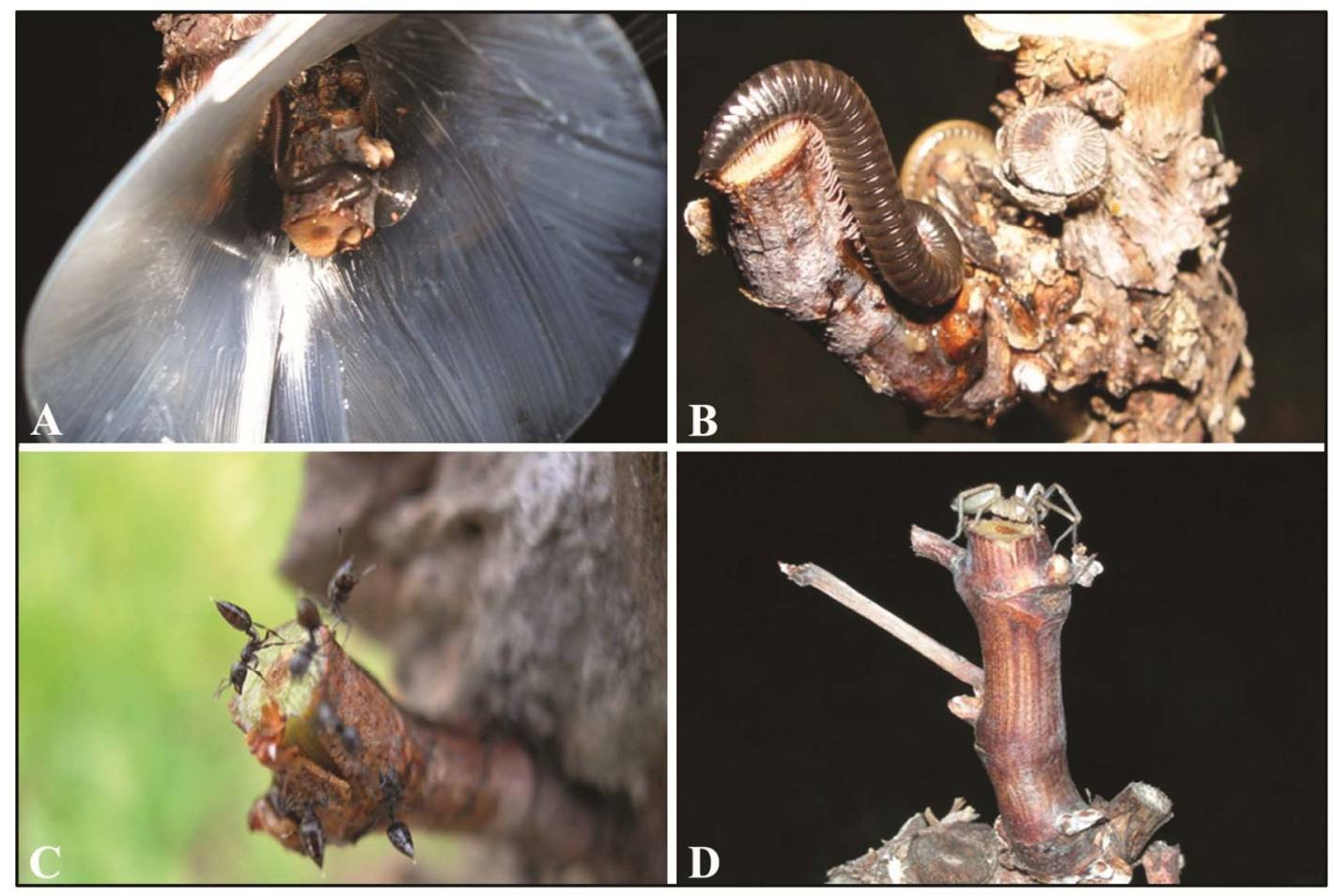

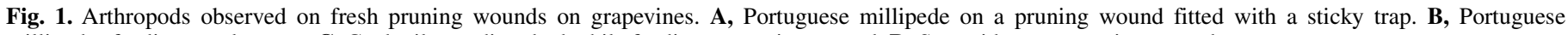
millipedes feeding on plant sap. C, Cocktail ants disturbed while feeding at pruning wound. D, Sac spider on a pruning wound. 
into one tube but the tubes were regarded as one sample. The possibility exists that clean individuals were present in samples with more than one arthropod. Samples were vortexed for $60 \mathrm{~s}$ to loosen any fungal spores present on their exoskeletons (32). Arthropods were removed and stored in $100 \%$ ethanol. Each resultant water suspension $(1 \mathrm{ml})$ was transferred onto potato dextrose agar (PDA; Biolab, Midrand, South Africa) plates containing chloromycetin $\left(250 \mathrm{mg} \mathrm{liter}^{-1}\right)$. Plates were incubated at 23 to $24^{\circ} \mathrm{C}$, exposed to approximately $12 \mathrm{~h}$ of daylight and $12 \mathrm{~h}$ of darkness, and inspected daily for 4 weeks for growth of trunk disease pathogens. Identification of pathogens was achieved using cultural and morphological characteristics of all species of Botryosphaeriaceae (38), Diaporthales (27), and Diatrypaceae (17); P. chlamydospora (7); as well Phaeoacremonium spp. (28).

Screening of arthropods for presence of pathogens using molecular techniques. The protocol described by Retief et al. (31) was followed for extraction of DNA from the remaining 1-ml water samples obtained from washing of arthropods. Isolated DNA was subjected to a nested polymerase chain reaction (PCR) to detect DNA of P. chlamydospora and Phaeoacremonium spp. The primary PCR reaction amplified the internal transcribed spacers (ITS1 and ITS2) and the 5.8S ribosomal RNA gene with the fungal primers ITS1 and ITS4 (40). Two separate secondary PCRs were conducted to detect $P$. chlamydospora with the speciesspecific primer pair Pch1/Pch2 (35) and species of Phaeoacremonium with the genus-specific primer pair $\mathrm{Pm} 1 / \mathrm{Pm} 2$ (1). The 25- $\mu$ l primary PCR reaction contained $5 \mu$ of DNA, $1 \times$ PCR buffer, $2.5 \mathrm{mM} \mathrm{MgCl} 2$, bovine serum albumen at $1 \mu \mathrm{g} / \mu \mathrm{l}, 0.2 \mathrm{mM}$ dNTPs, $0.25 \mu \mathrm{M}$ each primer, and $0.65 \mathrm{U}$ of Bioline Taq polymerase. Reaction conditions were an initial denaturation step at $94^{\circ} \mathrm{C}$ for $3 \mathrm{~min}$; followed by 35 cycles of $30 \mathrm{~s}$ at $94^{\circ} \mathrm{C}, 30 \mathrm{~s}$ at $52^{\circ} \mathrm{C}$, and $60 \mathrm{~s}$ at $72^{\circ} \mathrm{C}$; and a final extension step at $72^{\circ} \mathrm{C}$ for $7 \mathrm{~min}$. Reaction mixtures for the secondary PCRs contained the same concentrations of reagents as the primary PCR except for DNA, $\mathrm{MgCl}_{2}$, and primer concentrations. The Pch1/Pch2 PCR contained $1.5 \mathrm{mM} \mathrm{MgCl} 2$ and $0.30 \mu \mathrm{M}$ each primer while the $\mathrm{Pm} 1 / \mathrm{Pm} 2 \mathrm{PCR}$ contained $3 \mathrm{mM} \mathrm{MgCl} 2,0.5 \mu \mathrm{M}$ each primer, and $0.8 \mathrm{mM}$ dNTPs. Reaction conditions for the Pch1/Pch2 PCR were similar to those of the primary PCR except that it was optimized to annealing and initial extension temperatures of $57^{\circ} \mathrm{C}$ at $30 \mathrm{~s}$ and $72^{\circ} \mathrm{C}$ at $40 \mathrm{~s}$, respectively. Reaction conditions of the Pm1/Pm2 PCR were as described by Aroca and Raposo (1).

Confirmation of morphological identifications of pathogens using PCR. The DNA extraction method described by Damm et al. (9) was used to extract DNA from mycelium of actively growing cultures obtained from direct plating. ITS1, ITS2, and the 5.8S ribosomal RNA gene were amplified as previously described for the identification of species in the families Botryosphaeriaeceae, Diatrypaceaecae, and Diaporthales. To identify species of Phaeoacremonium, the $\beta$-tubulin gene was amplified using the primers $\mathrm{T} 1$ (30) and $\mathrm{Bt} 2 \mathrm{~b}(16)$ in a $25-\mu \mathrm{l}$ reaction that contained $2 \mu \mathrm{l}$ of DNA and the same concentrations of other reagents as the Pch1/Pch2 PCR; reaction conditions were as described by Mostert et al. (28).

All PCRs were performed in a GeneAmp PCR system 9700 (Applied Biosystems, Foster City, CA) and all PCR products were visualized under UV light on a $1 \%$ agarose gel containing ethidium bromide. PCR products were purified and sequenced as described by White et al. (41). Species were identified using the megablast function of the National Center for Biotechnology Information's GenBank nucleotide database (www.ncbi.nlm.nih.gov).

Grapevine sap as food source for suspected main vectors of pathogens. The most abundant arthropod taxa found to regularly carry spores of pathogens included spiders, Portuguese millipedes (Ommattoiulus moreleti Lucas), and cocktail ants (Crematogaster peringueyi Emery). Because there is a strong possibility that ants and millipedes use pruning wounds to feed on sugar-rich sap (36), all subsequent experimentation focused on these taxa.
Millipedes. Portuguese millipedes were collected from the cordons and trunks of grapevines as well as from plant debris in a 'Cabernet Sauvignon' vineyard at Nietvoorbij during July 2012. Individuals were placed in 9-cm-diameter petri dishes and starved for $8 \mathrm{~h}$. Grapevine sap was collected by cutting shoots from Cabernet Sauvignon grapevines and collecting the sap at the surface with a pipette. One drop $(200 \mu \mathrm{l})$ of water and one drop $(200 \mu \mathrm{l})$ of sap was placed at opposite sides of the petri dish approximately $60 \mathrm{~mm}$ apart and approximately $15 \mathrm{~mm}$ from the side. The positioning of the water or sap samples in the petri dishes was such that, in half of the plates, the sap was on the right and, in the other half, the sap was on the left. The experiment was replicated with 30 different individual millipedes. In addition, 20 millipedes were presented with two $200-\mu$ d drops of water only in the same experimental setup.

A single millipede per petri dish was placed at the edge of the dish, halfway between the two drops. Observations were made every $30 \mathrm{~min}$ (approximately $1 \mathrm{~min}$ of observation time) for a total observation period of $4 \mathrm{~h}$. The experiment was conducted at night in the dark and repeated once. The drop from which the millipedes were presumably feeding (with mouthparts on the drop) was noted and the total number of individuals observed to ingest water, sap, or nothing was recorded. The millipedes were recorded as having ingested a substance regardless of how many times they were observed to feed and were assumed to have fed on both items if they were observed to have mouthparts in contact with both drops during the experiment. The number of millipedes that ingested or did not ingest a substance during the two nights of experimentation was combined. A $\chi^{2}$ test was conducted using the Freq Procedure of SAS statistical software (version 9.2; SAS Institute Inc., Cary, NC) to test the null hypothesis that the number of millipedes that ingested a substance was independent of the identity of the substance.

Cocktail ants. Grapevine wood containing nests of cocktail ants were collected from a Chenin blanc vineyard in Rawsonville in July 2012 and kept under laboratory conditions in perspex boxes measuring 600 by 450 by $300 \mathrm{~mm}$. Food was withheld from the ants for $24 \mathrm{~h}$ prior to experimentation. The experiment was replicated seven times. Pieces of wood containing ant nests were placed at the center of boxes, while food samples were placed at opposite ends of the boxes. Ants were offered a choice of $0.5 \mathrm{~g}$ of tuna, $0.5 \mathrm{ml}$ of water, or $0.5 \mathrm{ml}$ of grapevine sap. The different food items were placed in petri dishes $(65 \mathrm{~mm}$ in diameter), with two petri dishes of each food item at opposite ends within each box. The number of ants observed feeding on each item was recorded at 15-min intervals (approximately $1 \mathrm{~min}$ of observation time) for a total duration of $3 \mathrm{~h}$. The total number of ants found feeding on a particular food item during the entire observational time was used for statistical analyses. Data were analyzed using the General Linear Model one-way analysis of variance in SAS (version 9.2), with the number of ants (counts) found on each item as the dependent variable and the independent variable treated as a fixed effect. This was followed by a least significant difference post hoc $t$ test $(\alpha=0.05)$ to compare means. Count data were $\log (x+1)$ transformed prior to statistical analysis and replicates were entered as block factors.

Transmission of fungal propagules from arthropods to pruning wounds. Fungal isolate and plant material. A DsRedExpress-transformed P. chlamydospora isolate (STE-U 6520) (25) from the Stellenbosch University culture collection was used for experimentation to ensure that the original experimental isolate could be traced. The fungus was maintained in petri dishes containing PDA for 14 days at $24^{\circ} \mathrm{C}$ prior to experimentation.

One-year-old rooted, dormant 'Chardonnay' canes were planted in individual plastic pots in a glasshouse. In all, 30 vines were used for each of two treatments (inoculations with spore-carrying cocktail ants or millipedes) and 10 served as controls for each treatment. A cylinder, constructed from transparency paper, was 
placed around each plant and covered with cheesecloth. Cylinder bases were secured to pots to prevent arthropods from escaping. Soil within pots was covered with filter paper to prevent arthropods from digging into the soil. A single shoot per vine was pruned immediately prior to release of arthropods into experimental chambers. Thereafter, plants were maintained in a glasshouse at 23 to $25^{\circ} \mathrm{C}$ for 1 month before isolations were carried out.

Arthropod collection, treatment and inoculation of experimental chambers. Millipedes and ants were collected from the above-mentioned vineyards. Millipedes were washed in distilled water for $10 \mathrm{~s}$ and dried using filter paper. Because of their small size, ants were not washed. Millipedes ( 3 per petri dish) and ants (30 per petri dish) were exposed to sporulating colonies of the DsRed-Express-transformed $P$. chlamydospora in petri dishes for $24 \mathrm{~h}$, transferred to the filter paper in potted plants, and left for 3 days, after which they were removed. In total, 3 millipedes or 10 ants were placed in each chamber. Control plants received the same numbers of ants and millipedes but these were initially placed onto sterile PDA plates.

Transmission of inoculum onto pruning wounds. One month after exposure to ants or millipedes, pruned shoots were removed and examined for the presence of DsRed-Express-transformed $P$. chlamydospora. The pruned pieces were surface sterilized by immersion in $70 \%$ ethanol for $30 \mathrm{~s}$, for $60 \mathrm{~s}$ in $3.5 \%$ sodium hypochlorite, and again for $30 \mathrm{~s}$ in $70 \%$ ethanol. Shoots were then split longitudinally and small wood fragments ( 1 by $2 \mathrm{~mm}$ ) were cut from either side of the pith at the interface between the dead and live tissue at the pruning wound and plated onto PDA amended with chloromycetin (250 mg liter $\left.{ }^{-1}\right)$. Dishes were incubated at 23 to $24^{\circ} \mathrm{C}$ and monitored daily for fungal growth for 4 weeks. The fluorescence of the $P$. chlamydospora colonies growing on the PDA plates was confirmed using an epifluorescence microscope (Zeiss Axioskop, Germany).

Millipede fecal pellets as sources of inoculum on grapevine pruning wounds. Because millipede feces were commonly observed on many pruning wounds in vineyards, we investigated the possibility that fecal pellets could act as inoculum sources for grapevine trunk pathogens. Millipedes were collected from a Cabernet Sauvignon vineyard at Nietvoorbij and placed in petri dishes ( $n=15$ dishes, each with three millipede individuals) containing PDA with 2-week-old colonies of $P$. chlamydospora for $24 \mathrm{~h}$. Millipedes for the control experiment were placed on PDA dishes $(n=8)$ without any fungal colonies. Thereafter, millipedes were surface sterilized by vortexing for $60 \mathrm{~s}$ in sterile water (in 50-ml Falcon tubes), vortexing for $30 \mathrm{~s}$ in $2.5 \%$ sodium hypochlorite, vortexing in $70 \%$ ethanol for $10 \mathrm{~s}$, and vortexing for $60 \mathrm{~s}$ in sterile water. This final wash step was repeated, after which individuals were dried on sterile paper towels, placed in empty, sterile petri dishes, and left overnight. Fecal pellets of these millipedes produced overnight were transferred to $2-\mathrm{ml}$ tubes containing $1 \mathrm{ml}$ of sterile water and suspended by maceration. The fecal matter suspension $(100 \mu \mathrm{l})$ was plated on PDA and monitored for the growth of $P$. chlamydospora. We also tested the efficacy of the surface sterilization technique by plating water samples from the final millipede wash step. Samples were centrifuged for $10 \mathrm{~min}$ at 10,000 rpm in an Eppendorf centrifuge 5810R (Eppendorf International, Hamburg, Germany), the supernatant was discarded, and the pellets were resuspended in $200 \mu \mathrm{l}$ of sterile water. This suspension $(100 \mu \mathrm{l})$ was plated onto PDA and monitored for the growth of $P$. chlamydospora. The experiment was repeated once.

\section{RESULTS}

Arthropods associated with declining grapevines and pruning wounds. In total, 10,875 arthropod individuals from more than 31 families were collected during the 2 years of sampling: 6,402 from the Chenin blanc and 4,473 from the Pinotage vineyard. The majority belonged to the orders Hymenoptera (ants and wasps, 28\%), Coleoptera (beetles, 10\%), Araneae (spiders, 9\%), and Diplopoda (millipedes, 41\%). The abundance of taxa in the two vineyards is shown in Table 1.

Although only a single species of millipede ( $O$. moreleti) was collected, it was very abundant (Table 1). Millipedes were not often found on pruning wound traps but were observed in large numbers on fresh pruning wounds at night (Fig. 1A and B). Cocktail ants ( $C$. peringueyi) dominated the Hymenoptera from declining grapevines and were commonly collected from pruning wound traps (Table 1). They were also observed in large numbers on pruning wounds (Fig. 1C). Spiders were represented by more than 15 families, of which Theridiidae (web spiders), Gnaphosidae (ground spiders), and Miturgidae (long-legged sac spiders) were most abundant. Many species were collected on pruning

TABLE 1. Arthropods collected from trunks, cordons, and pruning wounds from 'Chenin blanc' and 'Pinotage' vineyards and tested for the presence of trunk disease pathogens, using plating and molecular techniques

\begin{tabular}{|c|c|c|c|c|}
\hline \multirow[b]{3}{*}{ Taxon } & \multicolumn{4}{|c|}{ Number of arthropod individuals (\% positive) $)^{\mathrm{a}}$} \\
\hline & \multicolumn{2}{|c|}{ Chenin blanc } & \multicolumn{2}{|c|}{ Pinotage } \\
\hline & Trunk \& cordons & Pruning wounds & Trunk \& cordons & Pruning wounds \\
\hline Hymenoptera & $2,434(51)$ & 267 (28) & $144(49)$ & $166(9)$ \\
\hline Parasitic wasps & 0 & $85(25)$ & 0 & $114(4)$ \\
\hline Crematogaster peringueyi & $2,365(52)$ & $169(32)$ & $2(50)$ & $16(6)$ \\
\hline Linepithema humile Mayr & $23(26)$ & $9(0)$ & $139(50)$ & $36(25)$ \\
\hline Coccinellidae & $124(14)$ & $14(36)$ & $216(13)$ & $10(0)$ \\
\hline Staphylinidae & 0 & $200(30)$ & 0 & $39(9)$ \\
\hline Elateridae & $44(23)$ & $3(33)$ & $2(0)$ & 0 \\
\hline Araneae & $657(29)$ & $79(28)$ & $256(28)$ & $19(21)$ \\
\hline Collembolla & $3(0)$ & $83(48)$ & $31(10)$ & $424(16)$ \\
\hline Unidentified arthropods & $48(21)$ & $40(8)$ & $72(19)$ & $59(13)$ \\
\hline Blattodea & $190(47)$ & 0 & $2(0)$ & 0 \\
\hline Thysanoptera & 0 & $14(0)$ & 0 & $7(0)$ \\
\hline
\end{tabular}

a Number of individuals that tested positive for grapevine trunk disease pathogens divided by the total number of individuals collected per taxa. 
wound traps and, on one occasion, a sac spider (Cheiracanthium furculatum Karsch) was observed patrolling a pruning wound at night (Fig. 1D). The most abundant beetle families were Coccinellidae (ladybird beetles) and Staphylinidae (rove beetles). The most abundant family of Hemiptera was Pentatomidae (stinkbugs). Staphylinidae, Thysanoptera (thrips), and parasitic wasps were only captured on pruning wound traps (Table 1).

Arthropods as carriers of grapevine trunk disease pathogens. In total, 1,873 of 5,677 (33\%) samples tested positive for trunk disease pathogens using both culturing and molecular techniques. Of these, $37 \%$ (685 of 1,873) was recovered from millipedes, $22 \%$ (420 of 1,873) from cocktail ants, and $15 \%$ from spiders. Cockroaches contributed $4 \%$; rove beetles $3 \%$; and Argentine ants, earwigs, and ladybird beetles $2 \%$ to the number of positive samples. The remaining taxa contributed $\leq 1 \%$ to positive samples. Millipedes, spiders, and cocktail ants were not only very common but also yielded the target pathogens frequently (Table 1). Members of the orders Collembola and Dermaptera, although not collected in very high numbers, also frequently produced positive samples (Table 1).

Of the 5,677 water samples (obtained from washing of the arthropods) tested using Pch1/Pch2 and Pm1/Pm2 primer sets,
721 tested positive for the presence of $P$. chlamydospora and 1,020 tested positive for Phaeoacremonium spp. Grapevine trunk disease pathogens isolated using culturing techniques included $P$. chlamydospora, Phaeoacremonium spp., and species from the families Botryosphaeriaceae, Diatrypaceae, and Diaporthales (Table 2). The prevalence of specific fungi differed between the two vineyards (data not shown). For example, Phaeoacremonium sicilianum Essakhi, Mugnai, Surico, and Crous was the most common species of Phaeoacremonium associated with arthropods and was mainly isolated from the Chenin blanc vineyard.

Grapevine sap as food source for millipedes and ants. Food type had a significant influence on ant visitation numbers $(F=$ 12.60, df $=6, P<0.05)$ with more workers of Crematogaster peringueyi preferring grapevine sap over tuna and water (Fig. 2). Of the 60 millipedes presented with a choice of water or sap, 46 were observed to feed at some time during the experiment. Significantly more individuals $\left(n=42, \chi^{2} \mathrm{df}=1=50.90, P<\right.$ $0.0001)$ ingested vine sap than water $(n=4)$. Of the 42 millipedes, 39 chose to feed on grapevine sap first, while only four chose to ingest water first. None of the 39 individuals that started feeding on grapevine sap switched to water at a later stage whereas three of the four that chose water first switched to the sap later

TABLE 2. BLAST (from GenBank) identification results of the fungal species isolated from the surface of arthropods collected from vineyards

\begin{tabular}{|c|c|c|c|c|c|}
\hline Fungal taxon & $n^{\mathrm{a}}$ & $\begin{array}{c}\text { Representative } \\
\text { culture }\end{array}$ & $\begin{array}{c}\text { Compared with } \\
\text { GenBank accession }\end{array}$ & $\begin{array}{l}\text { Similarity } \\
(\%)\end{array}$ & $\begin{array}{r}\text { Gaps } \\
(\%)\end{array}$ \\
\hline Aplosporella prunicola Damm \& Crous & 2 & PMC 339 & EF 564376.1 & 100 & 0 \\
\hline Cryptovalsa ampelina (Nitschke) Fuckel & 21 & PMC 109 & AY 920391.1 & 100 & 0 \\
\hline Diaporthe helianthi Munt.-Cvetk., Mihaljč. \& M. Petrov & 2 & PMC 128 & AJ 312353.1 & 99 & 0 \\
\hline Diplodia mutila (Fr.) Mont. & 1 & PMC 121 & JQ 411412.1 & 99 & 0 \\
\hline D. scrobiculata J. de Wet, Slippers \& M. J. Wingf. & 2 & PMC 198 & DQ 458899.1 & 98 & 0 \\
\hline D. seriata De Not. & 65 & PMC 161 & JQ 659282.1 & 99 & 0 \\
\hline Eutypa lata (Pers.) Tul. \& C. Tul. & 1 & PMC 123 & AY 462541.1 & 99 & 0 \\
\hline Eutypella australiensis Trouillas, Sosnowski \& Gubler & 1 & PMC 207 & HQ 692479.1 & 100 & 0 \\
\hline Eutypella sp. (Pers.) Sacc. & 2 & PMC 130 & HQ 008913.1 & 88 & 4 \\
\hline Neofusicoccum australe (Slippers, Crous \& M. J. Wingf.) Crous, Slippers \& A. J. L. Phillips & 1 & PMC 202 & EU 375516.1 & 99 & 0 \\
\hline N. parvum (Pennycook \& Samuels) Crous, Slippers \& A. J. L. Phillips & 2 & PMC 160 & AY 228097.1 & 99 & 0 \\
\hline Phaeoacremonium alvesii L. Mostert, Summerb. \& Crous & 2 & PMC 206 & EU 883990.1 & 97 & 3 \\
\hline P. parasiticum (Ajello, Georg \& C. J. K. Wang) W. Gams, Crous \& M. J. Wingf. & 8 & PMC 240 & HQ 605022.1 & 99 & 0 \\
\hline P. sicilianum & 225 & PMC 220 & FJ 872409.1 & 99 & 0 \\
\hline Phomopsis viticola (Sacc.) Sacc. & 14 & PMC 173 & FJ 790861.1 & 99 & 0 \\
\hline Spencermatinsia sp. & 4 & PMC 224 & EU 673323.1 & 99 & 0 \\
\hline Spencermartinsia viticola (A. J. L. Phillips \& J. Luque) A. J. L. Phillips, A. Alves \& Crous & 19 & PMC 174 & AY 905555.1 & 99 & 0 \\
\hline Togninia minima (Tul. \& C. Tul.) Berl. & 90 & PMC 397 & AY 179939.1 & 99 & 1 \\
\hline
\end{tabular}

a Total number of cultures.

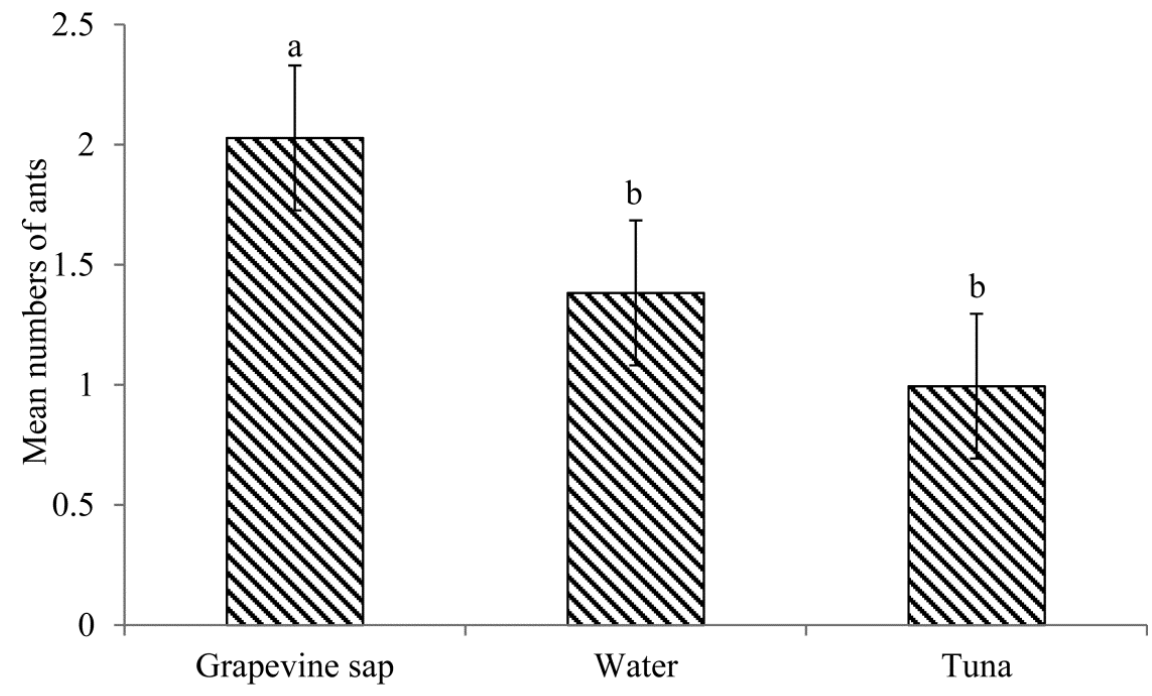

Food items

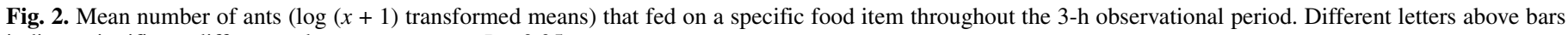
indicate significant differences between means at $P<0.05$. 
on. Only 3 of the 20 individuals that were offered only water were observed to drink.

Transmission of fungal propagules from arthropods to pruning wounds. Phaeomoniella chlamydospora was isolated from 47 and $27 \%$ of the pruning wounds on potted vines that were exposed to contaminated millipedes and ants, respectively. The fungus was not isolated from control plants. All isolates recovered were confirmed to be the DsRed-Express-transformed P. chlamydospora.

Millipede fecal pellets as sources of inoculum on grapevine pruning wounds. Surface sterilized millipedes placed in dishes containing agar or fungal colonies were not observed feeding on either; however, the presence of $P$. chlamydospora in the feces indicated that they ingested fungal colonies. In all, $73 \%$ (22 of 30 dishes each containing three individuals) of dishes housing millipedes that were initially placed on fungal colonies produced fecal pellets that contained high numbers of viable $P$. chlamydospora spores. $P$. chlamydospora was not detected in the remaining dishes, probably because these were overgrown by faster-growing fungi also present in the feces. P. chlamydospora was not recovered from feces of any of the control millipedes. Plating of water from final washings of millipedes after surface sterilization $(n=$ 46 replicates, each with three individuals) indicated that the sterilization technique was fairly effective, with only five dishes producing a few colonies of $P$. chlamydospora.

\section{DISCUSSION}

A large diversity of grapevine-associated arthropods carried spores of the Petri disease and esca pathogens, which were likely acquired while the carrier was hiding or nesting within cracks and crevices on diseased grapevine trunks. However, not all taxa that carried pathogens were commonly associated with fresh pruning wounds, making these unlikely vectors. In contrast, Portuguese millipedes and cocktail ants were very abundant within the vineyards studied and often carried spores of pathogens. They also regularly visited pruning wounds to feed on sap and they were able to cause infection of pruning wounds on healthy plants. Therefore, Portuguese millipedes and cocktail ants are considered effective vectors for grapevine trunk disease pathogens.

Most arthropods that tested positive for the target pathogens most probably only act as incidental vectors. Although not tested, it seems likely that the springtails collected in this study could feed on both grapevine sap (because numerous individuals were collected from pruning wounds) and fungi, as previously noted by Edwards et al. (10). A large proportion of these also carried the target pathogens, making them good candidates for effective pathogen transmission. However, due to their small size and wingless nature, they may have limited dispersal capabilities and probably do not play a major role in long-distance pathogen dispersal. In contrast, Staphylinid beetles, which often carried spores of the target pathogens (implicating a close association with the fungi), are winged and may be effective in long-distance dispersal of pathogens. Predatory arthropods like the spiders would only associate with pruning wounds to hunt for food, and their role in the dispersal of grapevine trunk disease pathogens remains to be tested.

Generally, millipedes are known to be detritivores (6), although some, like the Portuguese millipede, have also been reported to feed on living plant tissues (2), including grapevine leaves (F. Roets, personal communication). This study presents the first evidence that some taxa also feed on sap produced by wounded grapevines. Feeding on grapevine sap by cocktail ants is not surprising, given their high affinity for sugary food sources (24). Sap is usually only available for a day or two after pruning (field observations) but ants and millipedes continued to visit pruning wounds long after this. Therefore, it is likely that they also feed on the gum that forms on older wounds. This extended contact time may promote infection probability because wounds stay susceptible for pathogen colonization for up to 16 weeks after pruning (14).

Other studies noted the presence of fungal spores in droppings of arthropods, implicating them as dispersal agents $(12,23)$. In the current study, it was shown that $P$. chlamydospora can be transported in a viable state both externally and internally by millipedes. Millipede droppings were commonly observed on grapevine pruning wounds in the field and, therefore, may be a major contributor to infection. It is suspected that spores are ingested while millipedes clean themselves or feed on sap containing fungal spores. However, it still needs to be determined for how long P. chlamydospora present in millipede feces remains infective.

All the major fungal taxa associated with grapevine trunk diseases were isolated from the arthropods collected in this study. Specific fungal species were not restricted to specific arthropod species and, in some instances, a single arthropod individual carried more than one trunk disease pathogen simultaneously (data not shown). Because multiple grapevine pathogens can infect a single esca-diseased vine (42), arthropods could easily come into contact with spores of numerous taxa if these sporulate simultaneously. Interestingly, fungal taxa pathogenic to crops other than grapevines were also recovered from arthropods. For example, Aplosporella prunicola is associated with dieback symptoms of Prunus trees (8) and D. scrobiculata is a pathogen of Pinus spp. (4). Their pathogenicity on grapevines is currently unknown and whether their presence on arthropods has any economic importance remains unclear. However, the presence of such fungi on arthropods from grapevines suggests that arthropods may transport fungi between different host taxa, especially where these hosts occur in close proximity (e.g., pine or stone fruit trees are often planted around or near vineyards in South Africa).

Current management strategies for grapevine trunk diseases include chemical and biological protection of pruning wounds and sanitation practices (i.e., removal of dead or diseased grapevine wood) (29). Results from this study suggest that management of arthropods, particularly millipedes and ants, probably needs to form part of the management strategy to combat grapevine trunk diseases in vineyards. Ant control forms a significant part of agricultural practices in vineyards (19); however, no control is applied for Portuguese millipedes. Efforts to manage trunk diseases should include the prevention of arthropods accessing pruning wounds with the use of physical barriers such as stem barriers. Additional management practices, however, need to be evaluated on a per-taxon basis because some of these sporecarrying arthropods are beneficial in grape production systems. Some beetles (e.g., Coccinellidae), spiders, and species of Reduviidae tested positive for the trunk disease pathogens but are good control agents for many pest species, especially in vineyards under organic production. Therefore, the use of broad-spectrum insecticides is not advocated here and, for now, focus should fall on pruning wound protection, sanitation practices, and applying stem barriers.

\section{ACKNOWLEDGMENTS}

We thank Winetech, THRIP, NRF, and ARC for financial support; the Plant Protection Division (ARC Infruitec-Nietvoorbij) for technical assistance; and A. Dippenaar-Schoeman (ARC-Plant Protection Research Institute) for identification of spiders.

\section{LITERATURE CITED}

1. Aroca, A., and Raposo, R. 2007. PCR-based strategy to detect and identify species of Phaeoacremonium causing grapevine diseases. Appl. Environ. Microbiol. 73:2911-2918.

2. Baker, G. H. 1978. The distribution and dispersal of the introduced 
millipede, Ommatoiulus moreletii (Diplopoda: Julidae), in Australia. J. Zool. 185:1-11.

3. Baloyi, M. A., Eskalen, A., Mostert, L., and Halleen, F. 2013. First report of Togninia minima perithecia on esca-and Petri-diseased grapevines in South Africa. Plant Dis. 97:1247.

4. Bihon, W., Slippers, B., Burgess, T., Wingfield, M. J., and Wingfield, B. D. 2011. Diplodia scrobiculata found in the southern hemisphere. For. Pathol. 41:175-181.

5. Castillo-Guevara, C., Sierra, J., Galindo-Flores, G., Cuautle, M., and Lara, C. 2011. Gut passage of epigeous ectomycorrhizal fungi by two opportunistic mycophagous rodents. Curr. Zool. 57:293-299.

6. Crawford, C. S. 1992. Millipedes as model detritivores. Ber. Nat. Med. Verein Innsbruck 10:277-288.

7. Crous, P. W., and Gams, W. 2000. Phaeomoniella chlamydospora gen. et comb. nov., a causal organism of Petri grapevine decline and esca. Phytopathol. Mediterr. 39:112-118.

8. Damm, U., Fourie, P. H., and Crous, P. W. 2007. Aplosporella prunicola, a novel species of anamorphic Botryosphaeriaceae. Fungal Divers. 27:3543.

9. Damm U., Mostert, L., Crous, P. W., and Fourie, P. H. 2008 Novel Phaeoacremonium species associated with necrotic wood of Prunus trees. Persoonia 20:97-102.

10. Edwards, J., Laukart, N., and Pascoe, I. G. 2001. In situ sporulation of Phaeomoniella chlamydospora in the yard. Phytopathol. Mediterr. 40 (Suppl.):S61-S66.

11. Edwards, J., and Pascoe, I. G. 2001. Pcynidial state of Phaeomoniella chlamydospora found on Pinot Noir grapevines in the field. Australas. Plant Pathol. 30:67.

12. El-Hamalawi, Z. A., and Menge, J. A. 1996. The role of snails and ants in transmitting the avocado stem canker pathogen, Phytophthora citricola. J. Am. Soc. Hortic. Sci. 121:973-977.

13. Epstein, L., Kaur, S., and VanderGheyst, J. S. 2008. Botryosphaeriarelated dieback and control investigated in noncoastal California grapevines. Calif. Agric. 62:160-166.

14. Eskalen, A., Feliciano, A. J., and Gubler, W. D. 2007. Susceptibility of grapevine pruning wounds and symptom development in response to infection by Phaeoacremonium aleophilum and Phaeomoniella chlamydospora. Plant Dis. 91:1100-1104.

15. Eskalen, A., and Gubler, W. D. 2001. Association of spores of Phaeomoniella chlamydospora, Phaeoacremonium inflatipes, and Pm. aleophilum with grapevine cordons in California. Phytopathol. Mediterr. 40 (Suppl.):S429-S432.

16. Glass, N. L., and Donaldson, G. C. 1995. Development of primer sets designed for use with the PCR to amplify conserved genes from filamentous ascomycetes. Appl. Environ. Microbiol. 61:1323-1330.

17. Glawe, D. A., and Rogers, J. D. 1984. Diatrypaceae in the Pacific Northwest. Mycotaxon 20:401-460.

18. Kluth, S., Kruess, A., and Tscharntke, T. 2002. Insects as vectors of plant pathogens: Mutualistic and antagonistic interactions. Oecologia 133:193199.

19. Kriegler, P. J., and Whitehead, V. B. 1962. Notes on the biology and control of Crematogaster peringueyi var. angustior Arnold on grape vines. J. Entomol. Soc. South. Afr. 25:287-290.

20. Kubatova, A., Kolarik, M., and Pazoutova, S. 2004. Phaeoacremonium rubrigenum-Hyphomycete associated with bark beetles found in Czechia. Foilar Microbiol. 49:99-104.

21. Larignon, P., and Dubos, B. 2000 Preliminary studies on the biology of Phaeoacremonium. Phytopathol. Mediterr. 39:184-189.

22. Leach, J. G. 1940. Insect Transmission of Plant Diseases. McGraw-Hill Book Company, Inc., New York and London.

23. Lilleskov, A., and Bruns, T. D. 2005. Spore dispersal of a resupinate ectomycorrhizal fungus, Tomentella sublilacina, via soil food webs.
Mycologia 97:762-769.

24. Longino, J. T. 2003. The Crematogaster (Hymenoptera, Formicidae, Myrmicinae) of Costa Rica. Zootaxa 151:1-150.

25. McLean, T., Fourie, P. H., and McLeod, A. 2009. Reporter gene transformation of the trunk disease pathogen Phaeomoniella chlamydospora and biological control agent Trichoderma harzianum. Australas. Plant Pathol. 38:153-167.

26. Michelon, L., Pellegrini, C., and Pertot, I. 2007. First observations of esca disease in the Trentino area, northern Italy: Monitoring of spores, evolution of symptoms and evaluation of incidence. (Abstr.) Phytopathol. Mediterr. 46:105.

27. Mostert, L., Crous, P. W., Kang, J.-C., and Phillips, A. J. L. 2001. Species of Phomopsis and a Libertella sp. occurring on grapevines with specific reference to South Africa: Morphological, cultural, molecular and pathological characterization. Mycologia 93:146-167.

28. Mostert, L., Groenewald, J. Z., Gams, W., Summerbell, R. C., and Crous, P. W. 2006. Taxonomy and pathology of Togninia (Diaporthales) and its Phaeoacremonium anamorphs. Stud. Mycol. 54:1-115.

29. Mugnai, L., Graniti, A., and Surico, G. 1999. Esca (Black measles) and brown wood streaking: Two old and elusive diseases of grapevines. Plant Dis. 83:404-418

30. O'Donnell, K., and Cigelnik, E. 1997. Two different intragenomic rDNA ITS2 types within a monophyletic lineage of the fungus Fusarium are nonorthologous. Mol. Phylogenet. Evol. 7:103-116.

31. Retief, E., McLeod, A., and Fourie, P. H. 2006. Potential inoculum sources of Phaeomoniella chlamydospora in South African grapevine nurseries. Eur. J. Plant Pathol. 115:331-339.

32. Roets, F., Wingfield, M. J., Dreyer, L. L., Crous, P. W., and Bellstedt, D. U. 2006. A PCR-based method to detect species of Gondwanamyces and Ophiostoma on surfaces of insects colonising Protea flowers. Can. J. Bot. 84:989-994.

33. Rooney-Latham, S., Eskalen, A., and Gubler, W. D. 2005. Occurrence of Togninia minima perithecia in esca affected vineyards in California. Plant Dis. 89:867-871.

34. Stanghellini, M. E., and Russel, J. D. 1972. Germination In vitro of Pythium aphanidermatum oospores. Phytopathology 63:133-137.

35. Tegli, S., Bertelli, E., and Surico, G. 2000. Sequence analysis of ITS ribosomal DNA in five Phaeoacremonium species and development of a PCR-based assay for the detection of $P$. chlamydosporum and $P$. aleophilum in grapevine tissue. Phytopathol. Mediterr. 39:134-149.

36. Van der Meer, R., Jaffe, K., and Boulder, A. C. 1990. Applied Myrmecology: A World Perspective. Westview Presa, Boulder, CO.

37. Van Niekerk, J. M., Calitz, F. J., Halleen, F., and Fourie, P. H. 2010. Temporal spore dispersal patterns of grapevine trunk pathogens in South Africa. Eur. J. Plant Pathol. 127:375-390.

38. Van Niekerk, J. M., Crous, P. W., Groenewald, J. Z., Fourie, P. H., and Halleen, F. 2004. DNA phylogeny, morphology and pathogenicity of Botryosphaeria species on grapevines. Mycologia 96:781-798.

39. Van Niekerk, J. M., Halleen, F., and Fourie, P. H. 2011. Temporal susceptibility of grapevine pruning wounds to trunk pathogen infection in South African grapevines. Phytopathol. Mediterr. 50 (Suppl.):S139-S150.

40. White, T. J., Bruns, T., Lee, S., and Taylor, J. 1990. Amplification and direct sequencing of fungal ribosomal RNA genes for phylogenetics. Pages 315-322 in: PCR Protocols, A Guide to Methods and Applications. M. A. Innis, D. H. Gelfand, and J. J. Sninsky, eds. Academic Press Inc., New York.

41. White, C., Halleen, F., Fischer, M., and Mostert, L. 2011. Characterisation of the fungi associated with esca diseased grapevines in South Africa. Phytopathol. Mediterr. 50:204-223.

42. White, C., Halleen, F., and Mostert, L. 2011. Symptoms and fungi associated with esca in South African vineyards. Phytopathol. Mediterr. 50 (Suppl.):S236-S246. 